\title{
COVID-19 Pneumonia in two Patients with Ankylosing Spondylitis Using Anti-TNF Agents
}

\author{
Anti-TNF Ajan Kullanan Ankilozan Spondilitli íki Hastada COVID-19 \\ Pnömonisi
}

Idris Kurt' ${ }^{1}$ Ebru Çakır Edis², Habibe Tülin Elmaslar Mert ${ }^{3}$

\section{Abstract}

The new type of coronavirus (SARS-CoV2) reported to have originated in China in December 2019 has spread rapidly all over the world and has become a global problem. COVID-19 is more common and more severe in people with such comorbidities as cardiovascular disease, hypertension and diabetes. There is a lack of consensus on whether rheumatological diseases and drugs used in their treatment increase the risk of developing COVID-19. There is also lack of data in literature regarding the development of COVID-19, especially in patients with Ankylosing Spondylitis. This case presentation relates to two patients with Ankylosing Spondylitis using antiTNF agents who were affected by COVID-19. The younger of the two, who had no comorbidities, healed quickly with antiviral and supportive therapy, while the older patient, who had cardiovascular and chronic kidney comorbidities, experienced an aggressive disease course and did not survive. The course of COVID-19 infection and mortality is strongly connected with underlying comorbidities. Our focus here is on rheumatological diseases, their immunosuppressive treatments and their impact on the course of the novel type Coronavirus infection, based on two cases of Ankylosing Spondylitis, in light of literature.

Key words: Ankylosing Spondylitis, anti-TNF agents, COVID-19.

\section{Özet}

Çin'de, Aralık 2019'da görülmeye başlanan yeni tip koronavirus (SARS-CoV2) hızla tüm dünyaya yayılmış ve küresel bir sorun haline gelmiştir. Kardiyovasküler hastalık, hipertansiyon, diyabet gibi komorbiditesi olan kişilerde COVID-19 daha sık rastlanmakta ve daha ağır seyretmektedir. Romatolojik hastalıkların ve bunların tedavisinde kullanılan ilaçların COVID-19 gelişme riskini artırıp arttırmadığı tartışmalıdır. Literatürde özellikle Ankilozan Spondilitli hastalarda COVID-19 gelişimi ile ilgili veri eksikliği mevcuttur. Biz bu olgu sunumunda Anti-TNF kullanırken, COVID-19 enfeksiyonu geçiren, iki Ankilozan Spondilit'liyi sunmayı amaçladık. Komorbiditesi olmayan genç hastamız, antiviral ve destek tedavisi ile hızlı şekilde iyileşti. Kronik kardiyovasküler ve böbrek hastalığı olan yaşlı hastamızın seyri daha ağır oldu ve hayat kaybı ile sonuçlandı. COVID-19 enfeksiyonun seyri ve mortalitesi, altta yatan komorbid hastalıklar ile yakın ilişkilidir. Ankilozan Spondilitli iki olgu örneği üzerinden romatolojik hastalıklar ve kullanılan immünsupresif tedavilerin yeni tip koronavirüs enfeksiyonu seyrine etkisini, literatür eşliğinde, tartışmayı amaçladık.

Anahtar Sözcükler: Ankilozan Spondilit, anti-TNF ajanlar, COVID-19.
'Department of Internal Medicine, Trakya University Medical Faculty, Edirne, Turkey

${ }^{2}$ Department of Pulmonary Medicine, Trakya University Medical Faculty, Edirne, Turkey

${ }^{3}$ Department of Clinical Microbiology and Infection, Trakya University Medical Faculty, Edirne, Turkey

\author{
'Trakya Üniversitesi Tıp Fakültesi, İç Hastalıkları Anabilim \\ Dalı, Edirne \\ ${ }^{2}$ Trakya Üniversitesi Tıp Fakültesi, Göğüs Hastalıkları Anabilim \\ Dalı, Edirne \\ ${ }^{3}$ Trakya Üniversitesi Tıp Fakültesi, Klinik Mikrobiyoloji ve \\ Enfeksiyon Hastalıkları Anabilim Dalı, Edirne
}

Submitted (Başvuru tarihi): 30.08.2020 Accepted (Kabul tarihi): 27.01.2021

Correspondence (iletişim): Idris Kurt, Department of Internal Medicine, Trakya University Medical Faculty, Edirne, Turkey

e-mail: idrisk8607055022@gmail.com 
An outbreak of pneumonia detected in December 2019 in China spread rapidly, and in January 2020, the underlying agent was discovered and identified as a new type of coronavirus named SARS-CoV2 (Severe Acute Respiratory Syndrome Coronavirus 2) (1). This disease spread around the world in a very short time and was declared a pandemic by the World Health Organization on March 11, 2020 (2).

Although the disease is mild in $81 \%$ of cases, it can cause severe pneumonia in $14 \%$ of patients and respiratory failure in $5 \%$. The presence of comorbidities is correlated with an increase in mortality. In particular, patients with cardiovascular diseases, diabetes, chronic lung disease and hypertension are at an increased risk of mortality (3). Patients under immunosuppressive therapy for the treatment of rheumatological diseases are considered to be at risk of developing coronavirus infection and experiencing its worst course. In particular, the elderly and those with underlying multisystemic disease(s) are considered in the high-risk category. Furthermore, it is thought that all antiTumor Necrosis Factor (anti-TNF) agents used in the treatment of these patients may increase the risk of developing COVID-19 (4). Despite these risk assessments, it is not clear whether rheumatological diseases, especially Ankylosing Spondylitis (AS), are an increased risk factor. In this case report, we present two patients with Ankylosing Spondylitis who were undergoing anti-TNF, and discuss their cases in the light of literature.

\section{CASE}

Case 1: A 61 -year-old male patient was under observation by rheumatology department for 26 years with a diagnosis of Ankylosing Spondylitis. The patient, who was taking Infliximab and Sulfasalazine, was using also Rivaroxaban due to atrial fibrillation. The patient had stage 3 chronic kidney disease and proteinuria due to secondary focal segmental glomerulosclerosis, and was not on dialysis. He had been treated for pulmonary tuberculosis around 40 years earlier. It was learned that the patient, who presented to our clinic with cough, fever and shortness of breath, had been started on anti-TNF (Infliximab) 6 days prior to the onset of complaints. A nasopharyngeal and oropharyngeal swab was taken from the patient who was evaluated in the outpatient clinic and a chest $X$ ray was carried out. Suspicious lesions on $\mathrm{x}$-ray radiograph led to Computed Tomography (CT) imaging, revealing bilateral and more prominent ground-glass infiltrations in the basal parts of lungs (Figure 1). The patient was hospitalized due to comorbid diseases and hypoxia.
Laboratory values showed $\mathrm{C}$ reactive protein at 5.67 $\mathrm{mg} / \mathrm{dL}$; sedimentation, $92 \mathrm{~mm} / \mathrm{second}$; urea, $99 \mathrm{mg} / \mathrm{dL}$; creatinine, $1.9 \mathrm{mg} / \mathrm{dL}$; and D-dimer, $2.35 \mathrm{mg} / \mathrm{L}$. In his clinical parameters, blood pressure was $110 / 60 \mathrm{mmHg}$; pulse, 87 beats $/ \mathrm{min}$; and fever, $38.0^{\circ} \mathrm{C}$. A physical examination revealed bilateral ankylosed knee joints, the cervical, thoracic and lumbar vertebrae were immobilized in an ankylosed manner, and the number of breaths was less than 20. The patient was initiated on hydroxychloroquine, oseltamivir (because influenza could not be excluded), oral azithromycin and parenteral ceftriaxone (bacterial infection could not be excluded). A coronavirus PCR test from a nasopharyngeal swab was positive. On the first day of hospitalization, the patient's fever continved but dropped on the second day. On the fourth day of treatment, the patient developed dyspnea and tachypnea and was given Favipiravir. No arrhythmia was detected on electrocardiography (ECG). The patient was taken to the Intensive Care Unit and intubated after lack of improvement in his clinical condition, and he died the same day.

Case 2: A 35-year-old male with a known diagnosis of Ankylosing Spondylitis, being followed by the rheumatology department, and on Anti-TNF (Golimumab) therapy due to a lack of improvement in pain under nonsteroidal anti-inflammatory drugs, was evaluated. At that time, his PPD (Purified Protein Derivative) skin test reaction, evaluated for latent tuberculosis, was less than five millimeters. The patient had been in close contact with a COVID-19 verified family member and complained of fever, cough and loss of taste and smell for a week. Nasopharyngeal and oropharyngeal swab samples were taken and a chest $X$-ray was carried out. Due to the absence of net infiltration on the X-ray, cross sectional imaging was performed. Bilateral, milimetric and ground-glass infiltrations located predominantly in the peripheral, were observed on a Computerized Tomography (Figure 2). When the patient was hospitalized, his clinical parameters were: blood pressure, 100/70 mmHg; pulse, 75 beats/min; and temperature, $37.0^{\circ} \mathrm{C}$. No abnormalities were identified based on a physical examination and laboratory parameters. Hydroxychloroquine was prescribed for Coronavirus, and as influenza virus and bacterial infection could not be ruled out, Oseltamivir and Azithromycin were also initiated. A PCR test result was positive. The patient had a fever on the first day of hospitalization, but no increase in temperature detected on the following days. The patient's temperature did not rise for approximately 72 hours, and 
finally his symptoms resolved. He was informed of all the isolation conditions before being discharged.

\section{DISCUSSION}

It has been observed that people with underlying disease(s) are affected more by COVID-19, and rheumatological diseases can be expected to fall under this category due to the course of the disease and the immunosuppressive agents used (5). There is, however, insufficient data in the literature to support this view. Aiming to overcome this, a database was developed for the recording of patients with rheumatological diseases and with COVID19. Rheumatoid arthritis was the most common disease identified in an evaluation of 872 cases recorded in this database up until May 18, while Ankylosing Spondylitis fails to make the top 10 (6). Although anti-TNF agents can be expected to pose a risk for COVID-19 development, a recent review reported there being insufficient evidence to support this (7). In a study evaluating 320 patients with chronic arthritis using anti-rheumatic drugs, only four developed COVID-19, and it was concluded that rheumatological diseases and their therapies do not represent an additional risk (8). One group of researchers has suggested that the cell entry and mechanism of action of the SARS-CoV2 virus can be controlled with antiTNF, and so can be included in the treatment $(9,10)$. It is known that a study has been launched in China analyzing the efficacy and safety of Adalimumab for the treatment of COVID-19 (1 1).

The most frequent symptoms seen in patients are fever, cough and malaise $(12,13)$. A multicenter study found gustatory and olfactory problems to be frequent in patients infected by COVID 19, occurring in 88 and 86.5 percent of cases, respectively (14). In the present study, the main symptoms were fever and cough. Our younger patient showed reversible gustatory problem.

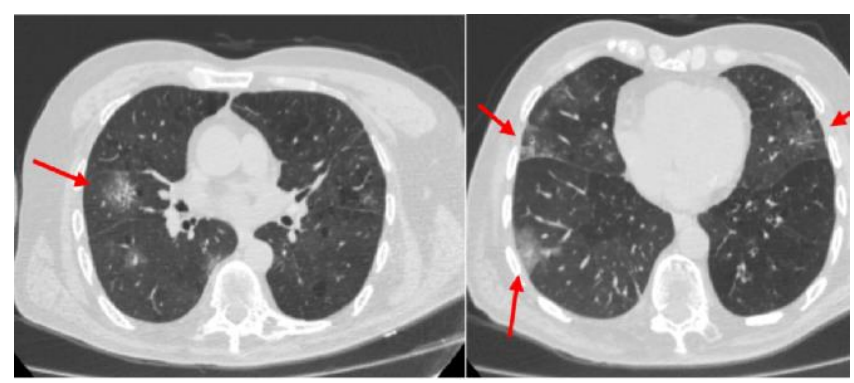

Figure 1: Bilateral ground-glass infiltrations

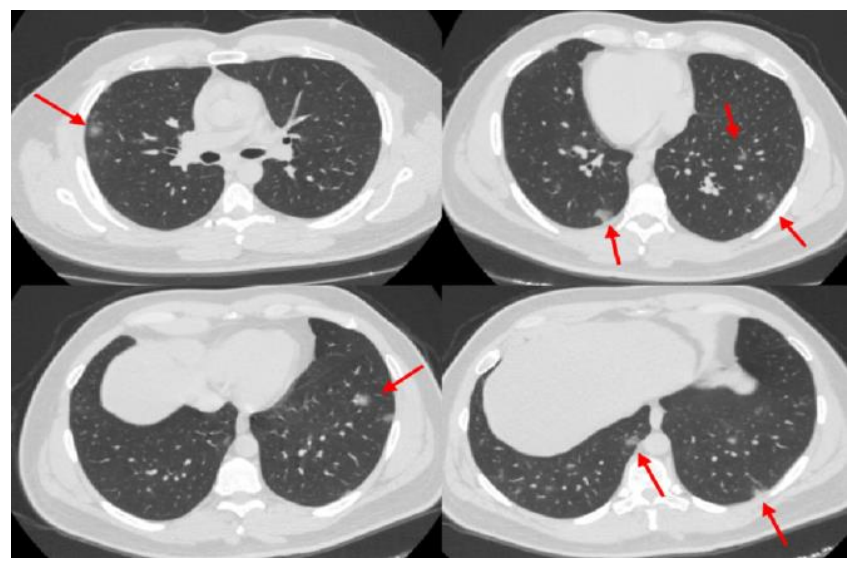

Figure 2: Bilateral, millimetric, weighted peripheral located ground-glass opacities

COVID 19 infections can be asymptomatic in some patients, but in the symptomatic state, the clinical spectrum is broad, ranging from fever, cough and dyspnea to death due to pneumonia, pulmonary edema, acute respiratory distress syndrome and organ failure (12).

Both of the patients in the present study had Ankylosing Spondylitis, with one receiving Golimumab and the other Infliximab. A review of literature revealed three studies of the outcomes of AS under the effects of COVID-19. One case report, in the form of a case-based review, comprised three patients and a letter to editor describing one patient (15-17). In first report, a patient with known hypertension and hypertriglyceridemia suffered from moderate pneumonia survived after the administration of antiviral agents and complementary corticosteroid therapy. The authors concluded that anti-TNF therapy may have had a positive effect on novel coronavirus pneumonia when introduced as early as possible (15). The second study relates to three patients with AS $(32,62,35$ year-old) of different ages, affected by COVID-19 while receiving Anti-TNF therapy (Infliximab, Adalimumab and Golimumab). The patients experienced a mild course of pneumonia and recovered with antiviral and supportive therapy. None of the patients had underlying comorbidities. The authors concluded that the mild form of infection seen in their patients had been due to an existing AntiTNF blockage (16). The last case was a 60 -year-old male with an AS diagnosis who was recovering from a mild form COVID-19 infection without therapy. The use of a TNF- $\alpha$ inhibitor prior to the viral infection was not associated with a severe evolution of the COVID-19 (17). In a case of AS undergoing Secucinumab (Anti-Interleukin 17A) therapy, a 61-year-old female patient without comorbidities presented with moderate pneumonia related to COVID-19, and was started on Tocilizumab due to 
significant infiltration of the lungs and elevated acute phase reactants. IL-17 inhibitors may serve as potential inhibitors of cytokine storm in COVID-19 infection (18). To the best of our knowledge, the present study is the fourth in literature assessing Ankylosing Spondilitis patients infected with novel type Coronavirus while on antiTNF therapy, but is the first to report a poor outcome. Both patients were infected with COVID-19 pneumonia, and the initial phase was moderate in both. The cases were hospitalized due to the need for close monitoring, oxygen supplementation and antiviral therapy. While both patients were under anti-TNF therapy prior to admission, the condition of the younger, without comorbidities, resolved quickly. The older patient, who had cardiovascular and chronic kidney diseases, suffered from a severe course of pneumonia that progressed, and the patient subsequently died. It would seem that mortality and morbidity in the novel Coronavirus infection are closely related to underlying comorbidities.

In conclusion, the course of the disease and mortality are strongly related to the type and number of underlying comorbidities. It is certain that more comprehensive and reliable studies are needed prior to making a definite comment on COVID-19 patients with Ankylosing Spondylitis, especially those on immunosuppressive therapy (particularly anti-TNF, as presented in our cases).

\section{CONFLICTS OF INTEREST}

None declared.

\section{AUTHOR CONTRIBUTIONS}

Concept - I.K., E.Ç.E., H.T.E.M.; Planning and Design I.K., E.Ç.E., H.T.E.M.; Supervision - I.K., E.Ç.E., H.T.E.M.; Funding -; Materials -; Data Collection and/or Processing - I.K., H.T.E.M.; Analysis and/or Interpretation - I.K., E.Ç.E., H.T.E.M.; Literature Review - I.K., E.Ç.E.; Writing - I.K.; Critical Review - I.K., E.Ç.E.

\section{YAZAR KATKILARI}

Fikir - I.K., E.Ç.E., H.T.E.M.; Tasarım ve Dizayn - I.K., E.Ç.E., H.T.E.M.; Denetleme - I.K., E.Ç.E., H.T.E.M.; Kaynaklar -; Malzemeler -; Veri Toplama ve/veya İşleme I.K., H.T.E.M.; Analiz ve/veya Yorum - I.K., E.Ç.E., H.T.E.M.; Literatür Taraması - I.K., E.Ç.E.; Yazıyı Yazan I.K.; Eleştirel İnceleme - I.K., E.Ç.E.

\section{REFERENCES}

1. Mclntosh K. Coronavirus disease 2019 (COVID-19): Epidemiology, virology, clinical features, diagnosis, and prevention. Available from: https://www.uptodate.com/contents/coronavirus-disease2019-covid-19-epidemiology-virology-clinical-featuresdiagnosis-and-prevention.

2. World Health Organization. "WHO Director-General's opening remarks at the media briefing on COVID-19-11 March 2020." Geneva, Switzerland (2020). Accessed 18.05.2020.

3. Wu Z, McGoogan JM. Characteristics of and Important Lessons From the Coronavirus Disease 2019 (COVID-19) Outbreak in China: Summary of a Report of $72314 \mathrm{Ca}$ ses From the Chinese Center for Disease Control and Prevention. JAMA 2020; 323:1239-42. [CrossRef]

4. Clinical guide for the management of rheumatology patients during the coronavirus pandemic. Available from: www.england.nhs.uk

5. Unity Amidst Uncertainty: COVID-19 Pandemic Fosters Collaboration in Rheumatology Community. Available from: www.thelancet.com/rheumatology.

6. Data from the COVID-19 Global Rheumatology Alliance Global Registry. https://rheumcovid.org/updates/combined-data.html (accessed date: 22.5.2020).

7. Russell B, Moss C, George G, Santaolalla A, Cope A, Papa $S$, et al. Associations between immune-suppressive and stimulating drugs and novel COVID-19-a systematic review of current evidence. Ecancermedicalscience 2020, 14: 1022. [CrossRef]

8. Monti S, Balduzzi S, Delvino P, Bellis E, Quadrelli VS, Montecucco C. Clinical course of COVID-19 in a series of patients with chronic arthritis treated with immunosuppressive targeted therapies. Ann Rheum Dis 2020; 79:667-8. [CrossRef]

9. Feldmann M, Maini RN, Woody JN, Holgate ST, Winter $G$, Rowland $M$, et al. Trials of anti-tumour necrosis factor therapy for COVID-19 are urgently needed. Lancet 2020; 395:1407-9. [CrossRef]

10. Favalli EG, Ingegnoli F, Lucia $O E$, Cincinelli G, Cimaz R, Caporali R. COVID-19 infection and rheumatoid arthritis: Faraway, so close. Autoimmun Rev 2020; 102523. [CrossRef]

11. Chinese Trial Clinical Registry. A randomized, open-label, controlled trial for the efficacy and safety of Adalimumab Injection in the treatment of patients with severe novel coronavirus pneumonia (COVID (ChiCTR2000030089). http://www.chictr.org.cn/showprojen.aspx?.proj=49889 
12. Wang D, Hu B, Hu C, Zhu F, Liu X, Zhang J, et al. Clinical characteristics of 138 hospitalized patients with 2019 novel coronavirus-infected pneumonia in Wuhan, China. JAMA 2020; 323:1061-9. [CrossRef]

13. Jiang F, Deng L, Zhang L, Cai Y, Cheung CW, Xia Z. Review of the clinical characteristics of coronavirus disease 2019 (COVID-19). J Gen Intern Med 2020; 35:1545-9. [CrossRef]

14. Lechien JR, Chiesa-Estomba CM, De Siati DR, Horoi M, Le Bon SD, Rodriguez A, at al. Olfactory and gustatory dysfunctions as a clinical presentation of mild-tomoderate forms of the coronavirus disease (COVID-19): a multicenter European study. Eur Arch Otorhinolaryngol 2020; 277:2251-61. [CrossRef]

15. Ye W, Lu S, Xue A. The potential role of TNFa in 2019 novel coronavirus pneumonia. Respir Med Case Rep 2020; 101087. [CrossRef]
16. Kaymaz S, Karasu U, Çobankara V, Alkan H, Ulutas F. Pneumonia complicated by SARS-coV-2 infection in three patients with ankylosing spondylitis who are on anti-TNF therapy: Case-based review. Indian J Rheumatol 2020; 15:341. [CrossRef]

17. Duret PM, Sebbag E, Mallick A, Gravier S, Spielmann L, Messer L. Recovery from COVID-19 in a patient with spondyloarthritis treated with TNF-alpha inhibitor etanercept. Ann Rheum Dis 2020; 79:1251-2. [CrossRef]

18. Coskun Benlidayi I, Kurtaran B, Tirasci E, Guzel R. Coronavirus disease 2019 (COVID-19) in a patient with ankylosing spondylitis treated with secukinumab: a casebased review. Rheumatol Int 2020; 40:1707-16. [CrossRef] 